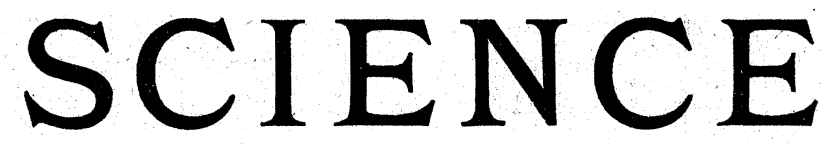

Editorial Committee : S. Newcomb, Mathematics; R. S. Woodward, Mechanics ; E. C. Pickering, Astronomy; T. C. Mendenhal, Physics; R. H. Thurston, Engineering; Ira Remsen; Chemistry;

J. Le Conte; Geology; W. M. Davis, Physiography; O. C. MARsH, Paleontology; W. K. Brooks, C. HART MerriaM, Zoology; S. H. Scudder, Entomology; N. L. BrItToN,

Botany; Henky F. Osborn, General Biology ; H. P. Bowditch, Physiology;

J. S. Bullings, Hygiene ; J. McKeen Cattell, Psychology ;

Danike G. Brinton, J. W. Powkel, Anthropology.

Fridax, September 11, 1896.

CONTENTS :

The Buffalo Meeting of the American Assaciation for the Advancement of Science :-

Address of the Vice-President before Section D.Mechanical Science and Engineering: The Artistic Element in Engineering: FranK O. MARvin...321

Address of the Vice-President before Section E.Geology and Geography: Geological Myths:

B. K. Emerson. .328

Section A.-Mathematics and Astronomy: E. B. Frost .344

Section B.-Physics : W. S. FRANKLIN . .346

The Physiology of Color in Plants: D. T. MACDoUGAL . .350

Current Notes on Anthropology:Mortuary Ceremonies: The Psychology of Primitive Man : D. G. BRINTON.

Scientific Notes and News:-

Scientific Research and Commercial Success; The German Zoological Society; Reports on Engine Trials of 1896; General.

University and Educational News.

Discussion and Correspondence:-

The Lick Review of 'Mars': A. E. Douglass. Commercial Mica in North Carolina: The Story of its Discovery: Frederic W. Simonds.

Scientific Literature:-

Williams' Manual of Lithology: M. E. WADswoRTH. American Linguistics: D. G. BRINTON. 361

Scientific Journals :

Psyche .364

New Books. .364

MSS. intended for publication and books, etc., intended for review should be sent to the responsible editor, Prof. J. McKeen Cattell, Garrison-on-Hudson, N. Y.
THE BUFFALO MEETING OF THE AMERICAN ASSOCIATION FOR THE ADVANCEMENT OF SCIENCE.

THE ARTISTIC ELEMENT IN ENGINEERING.*

A FRIEND of the writer, a successsful business man and much interested in things artistic, when informed of the choice of subject for this paper, gave expression to a feeling of surprise doubting if there was any relation between engineering and æsthetics.

One of the leading engineers of America once asked a professional brother what he did for recreation, and on being told of a modest interest in pictures and music likewise expressed surprise, saying, "You are the first engineer that $I$ have ever known to be a musician." There was also an implication, though unintentional, of a diminished respect-perhaps on both sides.

These two incidents may be taken to typify in a general way the attitude that is held by the business world, on the one side, and the engineering fraternity, on the other, towards the relationship which it is proposed here to discuss.

That the artistic element is not recognized as it might or ought to be in the present American day is natural. The rapid development and growth of our land, the intensive study of science and the concentration of the efforts put forth to adapt it to everyday affairs, has exalted one phase of

*Address of the Vice-President before Section D.Mechanical Science and Engineering. 
the economic idea, the quick attainment of profitable results, and clouded the truer, broader meaning that looks toward the best things and the highest life of the people. Into the midst of this active, restless, business life entered the engineer, doing more and more of its work and becoming more and more a recognized part of it and an undisputed element in its grow.th. He has acquired the characteristics of the life about him, zeal, energy, alertness, readiness in meeting quickly changing conditions, and absorption in the work in hand. $\mathrm{He}$ plans rapidly and executes to-day with an eye for to-morrow's profits. As another has said, "The world measures the efficiency of the engineer in dollars and cents," just in fact as it measures that of any other man, and engineers, as other men, largely accept the standard.

Time was when he was only the tool of some business man who had money to expend in a certain way and who employed him, under direction, because of some individual ability. But times are changing. In place of the isolated worker there is growing up a profession with professional standards and an esprit de corps, and whose members are to be retained, not hired. Cultured, and with the openness and clearness of mind that only come from deep study, broad training and large experience, these are to be people of influence. whose advice and services are sought; leaders, whose judgments are respected and men who can mingle with the best anywhere on a common ground of attainment and character. They are to be entrusted with the expenditure of public funds in increasing extent and with an augmenting confidence. The very nature of an engineer's qualifications, his technical knowledge, the cultivation of his judicial and critical faculty, his training in fidelity to the trusts reposed in him by private clients, all these fit him for places of large responsibility concerned with public works; and the people, tired of political management, are beginning to find this out.

These are no new thoughts, though none the less true, for others have recently written in confident strain of the coming engineer of the twentieth century. Yet it should be emphasized that the desired change is not, after all, so far ahead of us. To some extent, at least, the coming engineer has already arrived and is making himself felt. The leaven is at work.

With an engineering practice based solely on immediate results by way of expected profits in dollars and cents, the æsthetic element has little to do, though even here its absence may mean financial loss. But from the standpoint of this paper engineering is to be considered in the broader light. of Telford's well-known definition: "The art of directing the great sources of power in nature for the use and convenience of man,' while the engineer is he who designs and executes engineering works.

It is not necessary here to dwell upon the breadth and comprehensiveness of these simple fundamental statements, but let us. not forget that they are broad and comprehensive. With an engineering practice based on a generous interpretation of the above, the artistic has much to do.

The engineer is primarily a designer. He works with the materials of nature as his medium and her powers as his tools, wherewith to express his thought and his purpose to serve and benefit man. Just as in the making of a picture, the brushes, paint and canvas are not the chief things, so here it is not the stone, steel and brass. or the powers of gravity, steam, air and electricity that are most important, but rather the character and quality of the design and the degree of realization in its execution. The design may be bad or good, according as it ignores or harmonizes with principles underlying all such acts of cre- 
ation. The result may be a happy one only when the means employed are rightly chosen and properly adapted to the end sought. In this process of creating something of value, something that helps man to a fuller, richer and better life, the artistic cannot be left out. In its absence the design falls far short of its possible perfection and man is deprived of what is due him, though not perhaps distinctly conscious of the loss. In a certain sense then every engineer is an artist, and in some directions at least, as in architecture and other forms of construction and in the making of public parks, the result of his cultured brain may attain to the dignity of a work of ' fine art.' Perhaps, in its true essence, there may be as much fine art in the design of a machine to produce bolts as there is in the making of a picture for the Salon; certainly the well-planned tool with fine proportions and parts perfectly related is above the poor canvas.

To every true man there is a joy in creation that is not satisfied with anything less than the best of which he is capable. As Emerson has said, "I look on that man as happy who, when there is question of success, looks into his work for a reply, not into the market, not into opinion, not into patronage." *** "What is vulgar, and the essence of all vulgarity, but the avarice of reward? 'Tis the difference of artisan and artist, of talent and genius, of sinner and saint." But beyond this, which is the purely personal side of the matter, lies service, the designing for the use and convenience of man. From the vantage ground of his position as a man of educated intelligence and trained ability, the engineer owes the world his best effort. It needs and asks for technical skill and scientific knowledge whereby to-day's work may be done. But also, without knowing exactly what it wants, it feels the need of those added qualities it cannot define, and seeks for guidance and help to something better for to-morrow. In the long run, it will honor the man that meets the demand and will measure his efficiency on more grounds than that of dollars and cents.

To the superficial or hasty thinker there may appear a conflict here between the utilitarian and the artistic, but there can be no real antagonism. The result of an act of designing is to be judged as a whole in the light of all the purposes to be fulfilled. The physical conditions imposed by the materials used and the forces of nature employed are to be met. These conditions must be expressed in the design frankly and candidly, and in such a way as to indicate clearly its purpose and to gratify the observer through its proportions, symmetry, harmony and decoration. The end desired must be attained in the most direct and simple way, so that the expenditure of money may be a minimum. These are the three elements of design, scientific, æsthetic and the financial. A disregard of the requirements of the first may mean structural or organic weakness, on the one hand; or on the other, an excess of material that unduly adds to the cost and at the same time may produce heaviness or ugly proportions in the completed work. Non-compliance with the demands of the second makes the design fail in fulfilling its complete mission; this applies with the same force to those cases where a poorly directed attempt has been made to be artistic in expression, as to those in which no attention whatever has been paid to the matter. Artistic treatment often costs money, yet the mere expenditure of cash will not secure it. On the other hand, the proper display of good taste may often come without the spending of a dollar more than is made necessary by the other conditions surrounding the problem. A wealth of ornamentation may be brazen and vulgar, while beauty and grace may be found in the simple lines of a ma- 
chine or bridge, or in the curving of the curb by the roadside. The disregard of the financial side may mean either a weak, meagre and unsatisfactory result, or an unwise lavishness in expenditure, in both cases producing in the long run a loss and waste of money.

The current engineering practice gives great attention to the first and last of these elements, and but little comparatively to the second. There is no branch of it but would be benefited by adding to scientific and business ability a knowledge of the principles of artistic design and an impulse to give expression to it. The effect on the life of our communities and the Nation by such a change is not easily estimated, The writer does not expect, however, to see an immediate revolution. This is not a change that comes naturally in that way, but rather by way of development and growth, generally slow, although it may at times be accelerated. In this development our people as a whole must increase in artistic sensitiveness. We are not an rsthetic nation, but we have latent possibilities in that direction ; we are yourg, confident and impressionable and have the courage to be original in design, which counts for much. We have evolved the American locomotive, the American truss bridge, the American automatic machine, the American muchdebated tall building, and many other things especially adapted to American needs. We shall grasp the artistic possibilities of construction quickly when we come to know what they are, and will apply them confidently, not always at first with the most happy results. We shall learn something from the old world and will assimilate much that is good in its practice, but in the end engineering here will be both artistic and American.

There are evidences here and there that this process of change is going on. Ameri- can machine design when compared with that of other countries shows some marked characteristics. A writer in the Engineering Magazine says of these that "the best ones are directness of design, by which is meant the shortest cut to reach a given end, the designer having in mind the thing to be done quite as much as the machine which is to do it; lightness and a close proportioning of parts; in machine work a near approximation to pattern; rapidity of construction and rapidity of action in the finished machine; the substitution of special steels and new alloys, hollow construction, etc., for older materials and construction, and a generally neat appearance of work, and burrs, lips and roughness of casting removed. The American designer is not an artist like the Frenchman, but is more attentive to appearances than the Briton. $\mathrm{He}$ is gradually curing himself of the tendency to tawdry ornament, needless accessories of fancy castings, stenciled paints, japanning out of place and bright work for mere effect." These are good qualities and in the line of improvement. Some recent installations of power plants illustrate a movement that will have considerable influence on engine design. In many of our larger cities there are engine rooms fitted up in elegance, with marble floors and wainscott, decorated walls and ceilings; brilliantly lighted and with all the appliances of the plant, engines, dynamos, switch boards and even the smaller accessories in keeping with the surroundings. These plants are used as drawing cards or advertisements. There are other plants not so used, where there is displayed less elegance, but fully as much artistic sense in adapting the room and its treatment to its purpose. In many of these places only the enclosed type of engine can be used. In all of them the standard of maintenance must have its influence on the matter of design, which will in turn react on the 
former. An engine might pound itself to death in a dark basement, but would have its slightest vagary looked after in one of these better planned housings. This result cannot be entirely accounted for by the larger room, the better light, the rules and regulations. There is a refining, educating influence in these artistically planned constructions that makes better men and more efficient workmen of the attendants. Whatever they may cost, there is a credit side to the balance sheet.

Our railways are contributing toward this change. They have found the decoration of passenger trains a profitable thing and, so stimulated, have carried it to excess. Handsome terminal stations, adorned in good taste, are supplanting the dingy, forbidding and inconvenient places so long in use, while the shed type of depot is being crowded out by beautiful, quaint buildings set in the midst of lawns and flower beds. More significant still is the tendency to adopt a high standard of maintenance, under which the roadbed is kept trim and neat, flanked by sodded slopes and bordered by clean and well-kept buildings; which also requires the rolling stock, the shops and yards to be maintained in a high state of efficiency. This is not necessarily in itself artistic, but it furnishes at least a necessary foundation. That the railway management understands, to some degree, the commercial value of the artistic element in its business is further evidenced by the nature of its advertising, that seizes on any advantage of scenery or artificial effect that is at hand.

Not much can be said in praise of the artistic qualities of our bridges, for these attributes are conspicuous through their absence. The American bridge satisfies the conditions of stability and least cost, but of beauty of line or balanced proportion that make it fit into and harmonize with the landscape or even that makes it attractive considered by -itself, it has little. And this is to be the more regretted because an intelligent application of right principles would much improve the effect, without adding much, if any, to the cost or making the structure less safe and durable. It is true that the truss with parallel chords, especially of the through type, does not lend itself readily to artistic treatment, yet even here something can be done. It is not so much a matter of adding ornament as the proper treatment of the organic lines, the length of spans, the relation of length of panel to height of truss, the location of the piers and the form of their outlines. Ornamentation is not to be used so much for its own sake, but rather where it is needed to accentuate these organic markings. There are some truss bridges of such size that they give pleasure to the observer through their massiveness, though lacking in other desirable qualities. The cantilever, like the Pratt and its relatives, is difficult of treatment, while arch forms, either braced or of the suspension type, are naturally pleasing and best adapted for artistic expression. Of these types we have a few satisfactory examples, like the Eads and the Grand Avenue bridges at St. Louis, the Brooklyn and Washington bridges at New York. In our public parks are to be found many small bridges of good design, while in our cities there are some creditable ones of larger dimensions. There is some tendency toward the use of curved chords in bridges designed for urban use, and a further evidence of interest in the curved line through the introduction of the Melan arch. In some respects it is unfortunate that the economical element has driven out the stone arch, which possesses so many of the elements of a beautiful structure for most situations, and it may be that this new form will become a substitute for the old, with added characteristics of its own. However much we may admire the inventive genius and mechanical ingenuity 
of those who have worked out the types of rolling or lift bridges that cross the Chicago river, the less said about the beauty of the designs the better. Perhaps the environment imposes ugliness on the designer. But that problem is hardly solved yet, and will not be, until some man gets hold of it that combines rsthetic with scientific qualities and has insight keen enough to see the possibilities of the situation and adroitness enough to manage, not only the physical, but also the human factors - a rare combination.

In the entire field of engineering there is no portion of it that includes a greater variety of intricate and difficult problems for solution than that connected with municipal life. Here the engineer has to do with matters touching the home life; the dwelling, its heating, ventilation and lighting, its drainage and water supply, etc. There is the business life that demands attention for the stores, office blocks, banks and exchanges, manufactories and shops, warehouses and elevators with all of their requirements of heating, cooling, lighting, ventilation, drainage, power and internal communication through elevators, pneumatic systems and alarms. Then there is the larger life of the city as a whole that needs public buildings, churches, schools, hospitals, libraries, museums, hotels, thea.ters, railway stations and markets, each with its own peculiar demands; streets and systems for rapid transit, both intramural and suburban; the distribution of water, heat, cold, light and power; pneumatic systems for carrying packages; electrical conduits; sewerage and garbage systems, with the plants for their treatment or disposal; wharves and railway yards ; parks, boulevards, play grounds, plazas; the opening of new territory to accommodate the city's growth.

The engineer here comes in close contact with the people that daily and hourly use the results of his work. He already influences their health and bank accounts for the better, gives them greater ease and convenience at work or play and saves their time. This is what is asked of him and he meets the demand well. But what an uplift would come to city life, how much richer it would be, if he could put an artistic quality into his designing and the people would learn to appreciate it. It is not to be inferred that there is an entire absence of this, but rather that artistic effects have been largely confined to individual cases, and not made manifest in the general life of the city. For instance, there are numerous examples of suburban dwellings, beautiful internally and externally and with harmonious settings; there are occasional business blocks whose treatment is satisfactory, but very few public buildings that have an adequate artistic meaning and are so situated as to express this advantageously if they did posssss it. Without detracting in the least from the acknowledged merits of Trinity Church, Boston, it must be admitted that its roomy location on one side of an open plaza adds greatly to its effectiveness. Think of its being placed in the middle of a block on Washington street, or set in the midst of brownstone fronts on Fifth avenue! All public buildings need both room and an appropriate setting. They are the larger and more important pictures in the gallery of city structures; yet under the prevailing system of rectangular blocks, bounded by long, straight and narrow streets, the hanging committee has nothing but the walls of corridors on which to place them. The worst of the matter is that the exhibition is a permanent one. Along these alleyways must also be hung the narrow, vertically elongated panels that seem to be so popular to-day, in favor because they pay. The observer needs a twenty story ladder in order to study their details or even toknow if they have any and 
can find no point from which they can be seen as entireties. At their sides hang strings of pictures whose horizontality exaggerates their skyward tendency. It is not the modern tall building in itself that is here objected to, but its location on sites that will not admit of a display of its best qualities. With wide, clear surroundings and effective grouping they may be made agreeable, as is illustrated by the happy combination at the southeast corner of Central Park.

One of the good results of the tall building craze is the bringing closer together of two branches of designers ; from the architect the engineer will learn more of art and he will teach the former better construction. While retaining their separate functions, the collaboration will result in a higher mutual respect and appreciation and a better grade of work on the part of each.

It is undisputed that the rectangular plans of American cities are neither adapted to meet rsthetic conditions nor the demands of traffic. The long streets, without variation in width and direction and without the breaks afforded by little parks, are tiresome to the eye. They are not placed with any regard to the topography or the natural features of the landscape or to give prominence to some important structure, nor do they furnish direct lines of travel. But the plan is weighted down to the ground by millions of money. So it is not a question of what it ought to be, but one of mitigating the present evils and avoiding a repetition of these in the future. Radical treatment must be resorted to by way of diagonal avenues from congested centers and the widening out of the intersections of important streets into parks and plazas. There must likewise be a heroic struggle with the water fronts and internal water courses, places full of picturesque possibilities, though usually given over to filth and ugliness. These changes are made imperative not only by aesthetic requirements, but also by the demands of health and business.

In the planning of additions to large cities, the designer is hampered by the supposed necessity of tying to the older plans, by the desire of owners and speculators to realize to the largest extent on the sale of lots, or by his uncertainty as to what the future growth and character of the population may be. An examination of the block plan of many of our cities would show a heterogeneous arrangement of streets, especially in outlying districts, without regard to mutual relations, matters of grade and drainage or artistic position. This irregularity may be more inconvenient and less pleasing than a right-angled plan. Our towns and smaller cities reproduce in miniature the conditions of the larger centers. Here again it is a question of improvement instead of original design, only the problems involved are not so intricate and their solution not so costly. So it is hardly possible for a designer to plan an ideal city or to have the full swing and liberty of the men who laid out the city of Washington and established its system of grades and drainage. But in spite of difficulties there exist some suburban districts, laid out, built up and adorned on the principles of good taste. Thanks to the systems of rapid transit that are increasing the number of these attractive places!

In the design and maintenance of water supply plants, American practice shows some respect for the artistic element. This is not confined to any particular system or any part of any one plant, but is quite general: The engine houses are not ugly and their interiors are often attractive. Gate houses, aqueducts and dams are decoratively treated and form pleasing features in the landscape. The slopes of reservoirs are kept trimmed and the grounds 
generally turned. into lawns with flower beds and perhaps a fountain. No doubt, the sanitary conditions imposed have much to do with this, but the result is none the less in good taste. We cannot avoid, however, a stray shot at the ugly standpipe with conical cap, sometimes seen in our smaller towns. This is unnecessary. When enclosed it has been made an interesting object, and even the bare pipe can be ornamented in such a way as to relieve its nakedness.

There is much encouragement in the growing appreciation and enjoyment of public parks and boulevards. Cities and towns all over the land are trying to beautify what they already have and are adding new territory to their park resources. Admirable skill has been shown in utilizing the natural features of the local landscape, the rocks, tree masses, meadows, ravines, ponds and streams, the wide expanse of ocean or glimpses of bright water. The curving roads and paths, with undulating gradients, have a beauty of their own and lead one from point to point of the ever-changing scene, and yet bind it all into one harmonious whole. While the landscape engineer deserves credit, not so much praise can be given park commissioners for the artificial adornments which they have added to his work. Notwithstanding the fact that these are sometimes labeled as artistic, they do not always fit in appropriately.

The writer firmly believes that there is a latent æsthetic quality in American life that is now struggling to find both means for its gratification and methods of expression. Before there can be knowledge of its meaning and power there must be many attempts and many failures. The whole process is one of education and that largely in the school of experience. This applies to the industrial and constructive arts as well as to the fine arts. The engineer will share in the general movement, but this is not enough. As a designer of so much that the world needs for daily use he must do more than keep up; he must keep in advance. He must not only have a capacity to enjoy, but also the power to originate and apply. To this end he must give preliminary study and thought to the principles of æsthetic design, so gaining an intellectual knowledge of them. American engineering schools are doing little or nothing to help the young engineer to this. So far as the writer knows, there is but one American text-book, Prof. Johnson's book on bridges, that includes any discussion of the matter. A course of study in engineering æsthetics near the close of college life would be a great help and stimulus to a young graduate, at least opening his eyes to the fact that there was such a thing. After knowledge comes the application of principles as tests to an engineer's own work and to that of other men. And, finally, with theoretical and practical knowledge well in hand and a love of what is beautiful, comes the impulse to work artistically. With such engineers and an appreciative clientele American engineering would be artistic. To this end let us work.

Frank O. Marvin.

UNIVERSITY OF KANSAS.

\section{GEOLOGICAL MYTHS.*}

MANY years ago I visited the British flagship 'Bellerophon' in the harbor of Bermuda, and was told that when the ship was first named the sailors wrestled with the sonorous but unmeaning name, and quickly transformed it into 'Billy-ruffian,' and it became at once intelligible, and belligerent, and satisfying.

There arose, however, a contest in the forecastle as to whether 'Billy-ruffian' or 'Bully-ruffian' was the correct thing ; certain rude fellows of the baser sort wish-

* Address of the Vice-President before Section E, Geology and Geography. 